\title{
FORESTRY MEMORIAL SCHOLARSHIP
}

President Sidney Smith announces that: The Forestry Memorial Scholarship of $\$ 250.00$ has been awarded for the 1945.46 session to Donald James Vance in the Faculty of Forestry, University of Toronto, on the basis of his standing in the Ontario Grade XIII examinations. He entered first year For. estry in September last from Peterborough Collegiate Institute. Previous to high school he attended public school at Bancroft, Ontario.

Donald Vance is eighteen years old and is the son of Mr. and Mrs. John Vance of Bancroft. He is the fourth Forestry student to be awarded the scholarship which was established in honour of former members of the Forestry staff and in memory of graduates and undergraduates who have lost their lives in war activities or in civilian pursuits.

\section{Announcement by W. J. Dunlop,}

University of Toronto, November 27, 1945.

\section{EVERETT HOWARD ROBERTS}

E. H. Roberts, for many years Director of Forests, Saskatchewan, died suddenly on December 31, 1945, at the age of 52 .

Everett Roberts was born in Detroit and after graduating from Wyman's School of Forestry he was appointed to the faculty of the University of Toronto. From 1913 to 1917 he was chief of forest surveys for the Laurentide Paper Co. From 1919 to 1930 he was assistant forest inspector and district chief of fire protection in Saskatchewan for the Dominion Government. In 1930 he joined the Department of Natural Resources of the Province of Saskatchewan, and in his capacity as Director of Forests of that prov. ince has been well and favourably known in all parts of Canada.

E. H. Roberts' activities were innumerable. He was a director of the Canadian Forestry Association; an executive of the Boy Scouts Association; a member of the Advisory Committee on forestry, National Research Council; a member of the Veterans Civil Security Corps; a member of the Timber Control Advisory committee on pulpwood, and a life member of the Kinistino lodge, A.F. and A.M., Prince Albert.

He served as a private in the First Great War with the American Engineers and was later commissioned a lieutenant in the Air Service, U.S. Army.

For 30 years E. H. Roberts was a keen and active member of the Canadian Society of Forest Engineers, and at the time of his death was engaged, as Chairman of the Annual Meeting Committee, in making arrangements for the first meeting of the Society ever to be held in Regina. He was not to see these arrangements completed, but his kindly personality will live on in the hearts of his many friends.

Surviving are his wife, the former Elizabeth Wilkin of Prince Albert, and two sons, Major H. S. Roberts and Theodore, a student at Central Collegiate. To them we extend our deepest sympathy in their great loss. 